\title{
THE COOK IsLANDS, NiUE AND TOKELAU AS PARTS OF THE REALM OF NEW ZEALAND
}

\author{
Alison Quentin-Baxter
}

The focus of This Realm of New Zealand by Alison Quentin-Baxter and Janet McLean was on the constitutional monarchy and its relationship with the laws of mainland New Zealand. This article complements This Realm of New Zealand by focusing on the constitutional monarchy and its relationship with other countries of the Realm of New Zealand - the Cook Islands, Niue and Tokelau.

\section{INTRODUCTION}

\section{A "Our Realm of New Zealand"}

The Letters Patent Constituting the Office of Governor-General of New Zealand 1983 described the "Realm of New Zealand" as comprising five geographical areas: ${ }^{1}$
(a) New Zealand;
(b) The self-governing state of the Cook Islands;
(c) The self-governing state of Niue;
(d) Tokelau; and
(e) The Ross Dependency.

In that way, the Letters Patent acknowledge that the five parts of the Realm have a shared relationship with the Sovereign in right of New Zealand, while each retains its own legal system and laws. This article focuses on the ways in which the two self-governing states, the Cook Islands and Niue, and in many cases Tokelau also, exercise their roles as a part of the Realm of New Zealand. In a recently published book, the parts of that story which concern the Realm as a whole have been told. I summarise them briefly in this introduction. The main focus of the book is the way in which the constitutional monarchy affects the constitution and other laws of mainland New Zealand itself. But the story of how the monarchy affects the constitution and other laws of the Cook Islands and of Niue

* Dame Companion of the NZ Order of Merit, QSO.

1 Letters Patent Constituting the Office of Governor-General of New Zealand 1983 SR 1983/225. 
is yet to be told. They are the main focus of this article. For the sake of completeness, the article also touches on the monarchy as it affects Tokelau and the Ross Dependency, the remaining parts of the Realm.

\section{B The Story So Far}

In This Realm of New Zealand: The Sovereign, The Governor-General, The Crown published in $2017,{ }^{2}$ Professor Janet McLean and I explained that a "realm" is a kingdom. ${ }^{3}$ For a long time, the United Kingdom authorities clung to the doctrine that the Crown is indivisible, but when Queen Elizabeth II came to the throne, the divisibility of the Crown was acknowledged, in deeds if not in words. The Queen is now recognised as the Sovereign of 16 separate realms. One of them is New Zealand.

In chapter 6 of the book, Professor McLean and I discussed the making of the Letters Patent Constituting the Office of Governor-General of New Zealand 1983. The new document was made by the Sovereign herself, on the advice of the New Zealand Executive Council, and with the concurrence of the governments of the Cook Islands, Niue and Tokelau. ${ }^{4}$ There are also other contexts in which the Sovereign may need to be advised by someone who is entitled to speak for all the four inhabited parts of the Realm of New Zealand, or for one part in particular.

In the remainder of chapter 6 of the book we noted, first, the way in which the Cook Islands and Niue had become, in 1901, what are now parts of the Realm of New Zealand. In different ways the Ross Dependency, in 1923, and Tokelau, in 1925, also became what are now parts of the same Realm. ${ }^{5}$ We explain that ${ }^{6}$ the "Realm of New Zealand" is simply a convenient way of referring to all, or to any one or more, of the five countries or territories over which the Sovereign in right of New Zealand reigns.

Her roles in respect of each of the five parts of the Realm of New Zealand are very different from one another. The differences are the product of their different histories. They are reflected in their present day constitutions and other laws. As its full title indicates, the book explores the roles of the

2 Alison Quentin-Baxter and Janet McLean This Realm of New Zealand: The Sovereign, The GovernorGeneral, The Crown (Auckland University Press, Auckland, 2017) [This Realm]

3 At 1 .

4 That is in fact the only context in which the elected representatives of the four inhabited parts of the Realm of New Zealand can formally join in making law that apply to all five parts of the Realm of New Zealand, but the law so made will apply to a greater or lesser extent in each part of the Realm, because it remains subject to its own superior law.

5 This Realm, above $\mathrm{n} 2$, at 104-108.

6 At 99. 
Sovereign, the Governor-General and the impersonal Crown, but it does so mainly in respect of the state of New Zealand itself. In one context, however, it takes a wider view.

The book explains the principles that apply on the relatively few occasions when the government of a Commonwealth monarchy needs to tender formal advice to the Sovereign in person. Professor McLean and I looked at the principles that apply when advice needs to be tendered to the Sovereign on behalf of the Realm of New Zealand as a whole. ${ }^{7}$ Although the executive authority of each part of the Realm is vested in the Queen in right of the Realm of New Zealand, she is separately advised by the governments of New Zealand and those of the two self-governing states, the Cook Islands and Niue. ${ }^{8}$ The basic principle is clear: the Sovereign is entitled to be advised by one person who can speak for the Realm as a whole. ${ }^{9}$ The principles became established in 1926 when it became the right of "the Government of each Dominion to advise the Crown in all matters relating to its own affairs". 10 It was decided, however, that in the dominions with a federal system of government, Canada and Australia, it was impracticable to allow the government of a single state or province directly to advise the Crown. The Sovereign could not be expected to determine that a particular matter was indeed within its capacity. Advice should therefore be tendered to the Sovereign only by the Prime Minister of the country as a whole.

Formulated in that way, the principle meets the needs of a federal state. It needs to be adapted for five countries or territories that are part of the Realm of New Zealand. In the book, Professor McLean and I explained that the Prime Minister of New Zealand now has no constitutional role in the constitutions of either the Cook Islands or Niue. Of necessity, however, after consultation and agreement, he or she speaks to the Sovereign on behalf of the Realm on matters that affect it as a whole, such as the royal style and titles of the reigning Sovereign. In the law of the Cook Islands and of Niue, a reference to "the Sovereign in right of New Zealand" can be seen as a reference to the Sovereign with the attributes currently in force in New Zealand law. It is, however, implicit that the New Zealand government will have kept the governments of the other inhabited parts of the Realm informed, and obtained their agreement on any matter which might be controversial.

Outside that sphere, the associated states of the Cook Islands and of Niue, and in most cases Tokelau as well, have the right to speak to the Sovereign for themselves. Space did not permit us to explore that area in This Realm. A chapter drafted by Alison Quentin-Baxter had to be omitted. It now forms, substantially in its original form, the basis of the remainder of this article. As in the case

7 The principle does not apply to advice to amend or re-enact the Letters Patent Constituting the Office of Governor-General. As explained above, that matter is governed by its own set of rules: This Realm, above $\mathrm{n}$ 2 , at 99 .

8 The self-governing state of the Cook Islands and the self-governing state of Niue.

9 This Realm, above n 2, at 110.

10 At 111 
of the book, the author is grateful to the Clerk of the Executive Council for the permission to use the relevant files as a main source of information.

\section{THE TERRITORIAL REACH OF THE LETTERS PATENT}

The 1917 Letters Patent had applied to the geographical areas which, from 1840 on, the Sovereign had declared to have been "brought within the boundaries of" New Zealand. They then comprised New Zealand itself, including its outlying islands, and the more distant Cook Islands and Niue which had been annexed to the Crown in 1901. By 1980, however, a number of developments in the intervening years posed real questions about the geographical areas to which the new Letters Patent should apply.

In 1923, the Governor-General of New Zealand had been made the Governor of the Ross Dependency, ${ }^{11}$ a wedge-shaped slice of the Antarctic continent claimed by the United Kingdom government to be "part of Her Majesty's possessions". ${ }^{12}$ On behalf of the Sovereign, a secretary of state issued an instruction that, in exercising the functions of Governor of the Ross Dependency, the Governor-General was to be guided by the advice of the New Zealand Executive Council. ${ }^{13}$

Then, in 1925, Tokelau, a group of three small South Pacific atolls then known also as the Union Islands, were detached from the Gilbert and Ellis Islands, the United Kingdom colony to which they had been annexed. ${ }^{14}$ The Governor-General of New Zealand was appointed as Governor of Tokelau. ${ }^{15}$ His powers in that capacity were delegated to the High Commissioner of Western Samoa, the senior New Zealand official in what was then a League of Nations mandated territory administered by New Zealand. ${ }^{16}$

For the sake of completeness, it may be useful to explain that, although New Zealand administered Western Samoa, as it was then known, under the mandate, and later under a United Nations trusteeship agreement, Samoa was never brought within the sovereignty of the Crown. Accordingly, the Governor-General had no authority under the 1917 Letters Patent in respect of Samoa. The jurisdiction

11 "Order in Council for Government of the Ross Dependency" (16 August 1923) New Zealand Gazette 2211 at 2212.

12 At 2212 .

13 Despatch number 178 of 9 August 1923, preserved in the Archives of the Governor-General, reference G.484/3 "Antarctic and Arctic regions - Control (Ross Sea)" up to 1925.

14 "Union Islands (No 1) Order in Council 1925" (11 February 1926) New Zealand Gazette 398.

15 "Union Islands (No 2) Order in Council 1925", above n 14.

16 Order of the Governor-General cited as the "Union Islands (No 1 of New Zealand) Order 1926" (18 March 1926) New Zealand Gazette 659. The Order was subsequently amended by s 3(3) of the Samoa Amendment Act 1947. 
conferred by the mandate was, however, vested in the Sovereign, ${ }^{17}$ and Parliament invested the Governor-General with certain statutory powers. ${ }^{18}$ On 1 January 1962 Parliament recognised the independence of Samoa. ${ }^{19}$

Although the responsibilities of the Governor-General in respect of the Ross Dependency and Tokelau were exercised on the advice of New Zealand ministers, those ministers originally regarded their authority as that of an agent, acting on behalf of the United Kingdom government. By the end of World War II, however, it was apparent that changes in the relationships between the Sovereign and the British dominions recorded in the Balfour Declaration 1926 and the Statute of Westminster $1931^{20}$ had made the Crown divisible. Because the Governor-General was advised in respect of both the Ross Dependency and Tokelau solely by New Zealand ministers, New Zealand had been invested with an exclusive constitutional responsibility for both.

On 1 January 1949, with the agreement of the United Kingdom government, Tokelau was declared to form part of New Zealand. ${ }^{21}$ No such declaration has ever been made in respect of the Ross Dependency, but events were to confirm the exclusive and plenary nature of New Zealand's domestic law responsibility. On 1 December 1959 New Zealand signed the Antarctic Treaty. ${ }^{22}$ In order to give effect to the treaty in domestic law, Parliament then enacted the Antarctica Act 1960. Among other things, the Act provided for the trial and punishment in New Zealand of any person who, in the Ross Dependency, had done or omitted any act that would have been a crime if it had been done or omitted in New Zealand. ${ }^{23}$ The Antarctica Act can be seen as an exercise of New Zealand's territorial sovereignty in respect of the Ross Dependency, consistently, however, with the carefully drafted treaty provisions. ${ }^{24}$

At San Francisco in 1945, New Zealand's Prime Minister, Peter Fraser, had taken a leading part in the drafting of the United Nations Charter provisions about non-self-governing territories. His government decided that although the Cook Islands and Niue had been brought within the boundaries of New Zealand, both, together with Tokelau, were "non-self-governing countries" for the purposes of chapter XI of the United Nations Charter. Accordingly, New Zealand accepted the relevant Charter

17 "Western Samoa Order in Council" (4 June 1920) New Zealand Gazette 1819 at 1819.

18 Samoa Act 1921.

19 Western Samoa Act 1961, s 3.

20 This Realm, above n 2, at 1-6 and 142-167.

21 Tokelau Act 1948, s 3.

22 The Antarctic Treaty 402 UNTS 71 (opened for signature 1 December 1959, entered into force 23 June 1961).

23 Antarctica Act 1960, s 3.

24 See below for a brief discussion of the effect of the provision in New Zealand law and the law of the Ross Dependency itself. 
obligations in respect of all three territories. These included the obligation "to develop selfgovernment" in respect of each. ${ }^{25}$

The Cook Islands became self-governing on 4 August $1965 .{ }^{26}$ A decade later, Niue was ready to follow suit, and became self-governing on 19 October $1974 .{ }^{27}$ Those landmark developments revealed an element of divisibility even in the legal person of the Queen in right of New Zealand, originally regarded as a unitary concept. The new status of the Cook Islands and Niue as "self-governing states" clearly raised the question whether the new Letters Patent should still apply to them, as the 1917 Letters Patent still did.

\section{A Replacing an Outdated Concept}

The events just described showed clearly that New Zealand's relationships with each of the countries or territories concerned no longer depended on whether or not it had been brought within the boundaries of New Zealand. Although the relevant enactments are still part of New Zealand law, ${ }^{28}$ the so-called "boundaries" or "limits" were not borders which themselves signified the extent of New Zealand's territorial jurisdiction. ${ }^{29}$ They were simply straight lines of latitude and longitude enclosing certain islands or island groups for the purpose of identifying them. In most, if not all, cases the island or island group concerned had already been brought within the sovereignty of the Crown. Bringing it within the boundaries of New Zealand did, however, serve an essential purpose. In the years before New Zealand's adoption of the Statute of Westminster, it gave the New Zealand Parliament the necessary authority to make laws for its governance. ${ }^{30}$

That did not mean, however, that the laws applying to mainland New Zealand would necessarily have to apply to the country or territory that had newly been made part of New Zealand. Although that was so in the case of the outlying islands relatively near to its coasts, it was never the case in the Cook Islands or Niue. They were always administered under a separate sets of laws. Since 1947,

25 Charter of the United Nations, art 73(b).

26 Cook Islands Constitution Act 1964, ss 1(2) and 4; and Cook Islands Constitution Act Commencement Order 1965.

27 Niue Constitution Act 1974, s 1(2); and Niue Constitution Act Commencement Order 1974.

28 See, for example, the New Zealand Boundaries Act 1863 (UK) 26 and 27 Vict c 23 which bears the long title: "An Act to alter the boundaries of New Zealand", and, in the preamble, recites that it is expedient to alter the "limits" of the Colony of New Zealand. The Act is part of the laws of New Zealand: Imperial Laws Application Act 1988, s 3(1) and sch 1 .

29 Compare the different meaning of "limits" in the expressions "territorial limits of New Zealand", "limits of New Zealand", or a similar expression when used as a territorial description. Those expressions are defined as meaning the outer limits of the territorial sea of New Zealand: Interpretation Act 1999, s 29.

30 In chapter 1 of This Realm, above n 2, we explained that, originally, Parliament could make laws only for the territorial area described as "New Zealand": at 17. 
however, Parliament has had the "full power to make laws". ${ }^{31}$ There is no longer a shadowy restriction on their territorial reach. But Parliament itself has now irrevocably empowered the Cook Islands and Niue each to take itself out of the reach of laws made by the New Zealand Parliament, and both, in effect, have done so. In each, however, the executive authority continues to be vested in the Sovereign in right of New Zealand. Each still has some kind of constitutional connection with her representative in New Zealand, although the Cook Islands now has its own "Queen's Representative". It seemed clear, however, that both still had a constitutional connection with New Zealand that should continue to be recognised in the Letters Patent.

The 1980 report recommended that the new Letters Patent Constituting the Office of GovernorGeneral should take effect not only in New Zealand law, but also in the law of the Cook Islands, Niue, Tokelau and the Ross Dependency. For that purpose, all five states or territories should be regarded as continuing to be parts of a single "Realm of New Zealand". The new instrument would, however, need to take full account of the different sets of laws, usually referred to as "legal systems" in each part of the Realm, including the different arrangements for the governance of each, already in place or likely to be introduced within the foreseeable future.

That was the approach in drafting the new instrument. I now explain how it affects the interpretation of the 1983 Letters Patent, generally, and in the law of each part of the Realm.

\section{B The Need to Take Account of the Laws in All Parts of the Realm}

The 1983 Letters Patent provide that the Governor-General and Commander-in-Chief ${ }^{32}$ is the representative of the Sovereign "in and over Our Realm of New Zealand". The Governor-General has, and may exercise, in the whole of the Realm, the powers and authorities conferred by the Letters Patent. Those general provisions are made subject, however, to two overriding conditions.

First, the role of the Governor-General as the Queen's representative in the Realm of New Zealand is:

... without prejudice to the office, powers, or authorities of any other person who has been or may be appointed to represent Us in any part of Our Realm of New Zealand and to exercise powers and authorities on Our behalf.

That saving provision takes account, in particular, of the role of the Queen's Representative in the Cook Islands, and also the fact that, since 1924, the Governor-General has held a separate appointment as the Governor of the Ross Dependency. The implications of those roles are described below.

31 This Realm, above n 2, at 31-33.

32 The "Governor-General and Commander-in-Chief" is referred to as the Governor-General, unless the context otherwise requires. 
Secondly, as already mentioned, all the powers and authorities conferred on the Governor-General by the Letters Patent in respect of the Realm are governed by the general qualification "except as may be otherwise provided by law". That law may be the law of any part of the Realm. There is also an express provision requiring the Governor-General to exercise the powers and authorities of the office in accordance with "such laws as are now or shall hereafter be in force in Our Realm of New Zealand or any part thereof". The same principle is reflected in the oath for the due execution of the office. The Governor-General promises faithfully and impartially to serve the reigning Sovereign and the people of the Realm of New Zealand, "in accordance with their respective laws and customs". The Governor-General's roles are therefore distinct and different in respect of each part of the Realm.

\section{The Realm of New Zealand}

The references in the 1983 Letters Patent to "the Realm of New Zealand" are sometimes misunderstood. In reality, the Realm was simply a way of referring to all, or to any one or more, of the five countries or territories in respect of which the Sovereign in right of New Zealand is the head of state. In respect of the Ross Dependency, the role of the Governor-General has always been a large one, at least on paper. In respect of the Cook Islands, the Governor-General's role is now very small. In Niue, the Governor-General is the Sovereign's representative, but that does not give him or her the same role as that of the Sovereign's representative in New Zealand. There, the role has more significance than many believe, but less than some appear to think. Tokelau is truly "part of New Zealand" for the purposes of the Letters Patent.

The fact that the Governor-General has some role in respect of each part of the Realm was seen as making it desirable for the Letters Patent to be part of the law of every part. In the law of each part, however, the new instrument has a very different effect. The Realm is therefore the sum of its parts, not an entity in itself. On its face, the term is merely a drafting device, avoiding the need to list all the parts on every occasion, with the qualification that the term also means "any one or more of those parts, as the case requires". Historically, the Realm of New Zealand is the outcome of the individual legal and political relationships between New Zealand and each of the other parts of the realm. Those other parts have no direct links with one another.

To some extent, however, the concept of the Realm of New Zealand has taken on a life of its own. The role of the Sovereign in right of New Zealand as the head of state of all parts of the Realm can be seen as more than the recognition of a distant monarch. The common Sovereign symbolises the shared experiences and continuing status of the peoples of the Realm. Its populated parts are the homes of Polynesian peoples of the South Pacific. All were affected, in greater or lesser measure, by the explorers, traders and settlers from Europe and elsewhere that arrived on their shores. All parts of the Realm were annexed by the British monarch, colonised under the New Zealand flag, and affected by the received English law as well as that originating in New Zealand. Everyone who now belongs to any part of the Realm has, as of right, the status of a New Zealand citizen. Those factors give the Realm of New Zealand a reality going well beyond the words of the Letters Patent which gave it birth. 
At the same time, it is important to understand, not only what the Realm of New Zealand is, but also what it is not. The references in the Letters Patent to the Realm of New Zealand do not mean that New Zealand is a federal state. There is no Prime Minister or government of the Realm. Nor do Acts of the New Zealand Parliament become part of the law of the self-governing state of the Cook Islands or the self-governing state of Niue unless the law of the state concerned so provides.

The government and Parliament of New Zealand do, however, have legislative and executive authority in respect of Tokelau and the Ross Dependency, but each of those territories also has its own legal system conferring real legislative and executive powers in the case of Tokelau, and nominal powers in the case of the Ross Dependency. Accordingly, nothing can be seen as "the law of the Realm" unless, by a law-making process that its own law recognises, it has become the law of every part. In making the 1983 Letters Patent in the exercise of the prerogative constituent power, the Sovereign exercised the only legislative power that is common to the law of all parts of the Realm.

Although the executive authority of each part of the Realm is vested in the Queen in right of New Zealand, she is separately advised in respect of New Zealand and each of the two self-governing states. That principle, however, has to operate within the parameters of another: the Sovereign has a single adviser in respect of each of her realms.

\section{The Sovereign as the Head of State of All Parts of the Realm of New Zealand}

Once it had been recognised that the Crown is divisible, as among the Sovereign's different realms, it was also recognised that she must be able to look to a single adviser in respect of each. The convention first emerged in respect of the long-established federal states. In Canada, the Sovereign is represented not only by a Governor-General, but also by a Lieutenant Governor in each province. Similarly, in Australia, she is represented by the Governor-General, and also a Governor in each state. Those offices reflect the fact that the Canadian provinces and the Australian states were once separate colonies, each having its own relationship with the Sovereign. Even so, the Sovereign now acts only on the advice of the Prime Minister of Canada or of Australia as the case may be.

That practice is sometimes rationalised on the basis that the Canadian provinces and the Australian states are not "sovereign independent countries", ${ }^{33}$ but that formulation simply reflects the chain of events since 1926, when the governing principle was first enunciated: "[I]t is the right of the Government of each Dominion to advise the Crown in all matters relating to its own affairs." ${ }^{34}$ In the

33 Letter from Phillip Moore (Private Secretary to the Queen) to Arthur Porritt (Governor-General of New Zealand) CAB 165/3/2 (26 December 1970).

34 Inter-Imperial Relations Committee Imperial Conference 1926: Report, Proceedings and Memoranda Cmd 2768 (November 1926) at 5. See This Realm, above n 2, at 26. 
period since then, the "Dominions" have become the "Members of the Commonwealth", and, in the present context, those of them that have remained realms.

It was once usual to regard "sovereign independence" as a main criterion for "full membership" of the Commonwealth. On that basis, the units of a federal state did not qualify as separate members of the Commonwealth. "Sovereign independence" is now a rather dated way of referring to statehood in international law, ${ }^{35}$ and "full" membership of the Commonwealth no longer figures in recent discussions about eligibility to become a Commonwealth member. Even so, statehood is still relevant. In the present context, however, the criteria for admission as a member of the Commonwealth can be left to one side.

Although three parts of the Realm of New Zealand, the Cook Islands and Niue, as well as New Zealand itself, are "states" at international law, the first two remain freely associated with New Zealand, and are parts of a single "Realm of New Zealand". Constitutionally, however, the Prime Minister of New Zealand is not the Prime Minister of the Realm. He or she cannot speak for a selfgoverning state. Each has a Prime Minister or a Premier of its own.

The principle remains, however, that Her Majesty cannot be expected to determine the allocation of responsibilities as among the different parts of what remains a single realm. There must be someone with the authority to speak for the Realm as a whole, and able to advise the Sovereign on the status of its individual parts. History, as well as the law of some, but not all, parts of the Realm of New Zealand, has given that task to the Prime Minister of New Zealand. As will be seen, it has been necessary to work out a way of reconciling that accepted practice with the principle that the head of government in a self-governing state like the Cook Islands or Niue has the right to advise the Sovereign directly on a matter relating solely to that state. What may now be regarded as the governing conventions are explained below.

A similarly pragmatic approach has been taken to other matters concerning the Sovereign that affect each part of the Realm in the same way, and on which it is essential to maintain uniform law in all parts of the Realm. The main examples are the effect of a regency; a change in the royal style and titles, on a demise of the Crown or otherwise; a change in the law of succession to the throne; and the making or amendment of the Letters Patent constituting the Office of the Governor-General. On matters of that kind, the Prime Minister of New Zealand speaks to the Sovereign on behalf of the Realm, but only after consulting the governments of the self-governing states and, more recently, the government of Tokelau as well. ${ }^{36}$

35 James Crawford The Creation of States in International Law (2nd ed, Oxford University Press, Oxford, 2006) at 32 .

36 An assurance to that effect was given in the Joint Centenary Declaration of the Principles of the Relationship between New Zealand and the Cook Islands (signed 11 June 2001), cl 3(2). 
In the days before the self-government of the associated states, it was the practice to ensure that any change in New Zealand law on matters of that kind would take effect also in the law of the Cook Islands, Niue and Tokelau. That course is no longer possible in respect of the Cook Islands, and can occur in respect of Niue only at its request and with its consent, given by resolution of the Niue Assembly $^{37}$ - a procedure now followed rarely, if at all. Even in respect of Tokelau, the direct application of a New Zealand Act may not necessarily be the preferred option.

In the constitutions or other laws of all three, however, a reference, express or implied, to "the Sovereign in right of New Zealand" can be seen as importing by reference any change that may be made in New Zealand law in respect of the Sovereign, if it is clearly pertinent to her role in all parts of the Realm. On that basis, it can be seen as unnecessary expressly to amend the local law (although that would still remain an option). For that reason, it is all the more important that, before the New Zealand Parliament makes any such changes to its own law, the New Zealand government should observe what can be regarded as a constitutional convention requiring prior consultation with the other parts of the Realm.

The practice just described cannot, however, be seen as applying to a change to the law of New Zealand that would bring to an end the Sovereign's role as New Zealand's head of state. As a matter of law, the constitutions of the Cook Islands and of Niue can be changed only by the people of the self-governing state concerned, and the law of Tokelau should not be so changed unless its people so wish.

The governing principles are clear. The peoples of the Cook Islands, Niue and Tokelau have the right to maintain their allegiance to the Sovereign unless, in the exercise of their own free will, they decide not to do so. The people of New Zealand also have the same right to make their own decision. If they decide to move to a republican form of government, but the people of one or more of the other parts of the Realm wish to maintain their existing allegiance to the Sovereign, then ways must be found of giving effect to the respective decisions of each.

Obviously, there would no longer be a place in the law of any part of the Realm in its present form for references to the Sovereign "in right of New Zealand". What should be put in its place in the law of each will need careful consideration and an expression of its people's will. I discussed in ch 13 of This Realm some of the issues that seem likely to arise in respect of New Zealand. In respect of the other parts of the Realm, however, there is little point in speculating about possibilities that seem likely to be consequential on the decisions made in New Zealand. There is, however, no escaping the fact that any change in the role of the Sovereign in New Zealand's constitution will have implications for the role of the Sovereign and of the Governor-General in the other parts of the Realm.

37 Constitution of Niue, art 36. 


\section{THE SOVEREIGN AND THE GOVERNOR-GENERAL IN THE DIFFERENT PARTS OF THE REALM}

\section{A The Diverse Countries and Territories}

\section{The Governor-General essentially a New Zealand organ of government}

I now look at each part of the Realm in turn, with a view to identifying the constitutional roles of the Sovereign, and more particularly the Governor-General, in the constitutional arrangements of each. As shown in the book, however, that New Zealand is the hub of the Realm. The GovernorGeneral is essentially a New Zealand organ of government, advised by New Zealand ministers, and the role performed by the holder is woven into the fabric of the constitution as a whole.

In this part, we do no more than describe the territorial extent of "New Zealand", considered as one part of the Realm. In chapter 7 of This Realm, we looked closely at the office of Governor-General as constituted by the Letters Patent, and at the role of the Governor-General in the executive branch of government. The focus of chapter 8 of This Realm was the roles of the Sovereign and the GovernorGeneral in the other two branches of government, the legislative and the judicial branches. Then, in chapter 9 of This Realm, we looked at the relationship between the Governor-General and his or her responsible advisers in what might be called the marginal cases - those where the Governor-General has or may have an element of personal discretion.

\section{The Governor-General in the other parts of the Realm}

In respect of the parts of the Realm of New Zealand other than New Zealand itself, it is necessary to look at the role of the Governor-General from two viewpoints. To the extent that the government of New Zealand has a role in the governance of the part concerned or relations with it, the powers and authorities of the Sovereign, as delegated to the Governor-General and exercised on the advice of New Zealand ministers, are those routinely exercised in respect of New Zealand itself or New Zealand's relationships with other states.

We explained in the book that, although the Letters Patent are part of the law of all the parts of the Realm of New Zealand, they have effect in each part only so far as consistent with its other law. While therefore having greater or lesser practical relevance in the parts of the Realm other than New Zealand, the Letters Patent signify that, in those parts too, the Governor-General remains an essential link with the Sovereign in right of New Zealand.

That said, each other part of the Realm, has (notionally in the case of the Ross Dependency) its own governmental institutions. In these, the Governor-General plays a greater or lesser part. Generally speaking, the Governor-General still acts on the advice of New Zealand ministers, with two exceptions. First, the constitution of the self-governing state of Niue gives the Governor-General a 
distinct role, acting on the advice of his or her Niue ministers. ${ }^{38}$ Secondly, under its own constitution the self-governing state of the Cook Islands now has its own Queen's Representative, but the Governor-General, acting on the advice of the New Zealand Prime Minister, plays a part in transmitting to the Sovereign the advice of the Prime Minister of the Cook Islands on appointments to that office.

I now look more closely at each of the different parts of the Realm of New Zealand with a view to identifying the different roles of the Governor-General in respect of each.

\section{B New Zealand}

\section{The meaning of "New Zealand" as part of the Realm}

As a distinct part of the Realm of New Zealand, "New Zealand" comprises what are usually referred to as "the three main islands", ${ }^{39}$ together with all the islands adjacent to their coasts, and the more distant "outlying" islands or island groups. Those include the Chatham, Bounty, Antipodes, Auckland, Campbell, Snares, Three Kings and Kermadec Islands. Of those, only the Chatham Islands have a significant permanent population. Most if not all of the others have no permanent inhabitants.

Unless otherwise provided, the geographical area just described is "New Zealand" for the purposes of the statute law. The modern definition securing that result recognises New Zealand's place as part of the wider Realm: ${ }^{40}$

'New Zealand' or similar words referring to New Zealand, when used as a territorial description, mean the islands and territories within the Realm of New Zealand; but do not include the self-governing State of the Cook Islands, the self-governing State of Niue, Tokelau, or the Ross Dependency.

In some cases, however, Parliament has given "New Zealand" a wider meaning. In the Citizenship Act 1977, for example, "New Zealand" includes the Cook Islands, Niue, Tokelau, and the Ross Dependency. ${ }^{41}$ That usage is merely a drafting device, but it illustrates the fact that New Zealand

38 In carrying out the role conferred by the Constitution of Niue, the Governor-General acts on the advice of the Niue Cabinet: below, Part III, D, 5 .

39 The North Island, the South Island and Stewart Island. "Mainland" or "metropolitan" New Zealand are other ways of referring to those islands (but, as the largest island of the group, the South Island is sometimes referred to metaphorically as "the Mainland").

40 Interpretation Act, s 29, definition of "New Zealand".

41 Citizenship Act 1977, s 2(1). The definition does not have the effect of giving the Act the force of law in any other part of the Realm. Even so, such a definition would not normally be included without the express or implied agreement of the government of a part of the Realm included in that way. In the case of the Citizenship Act, the governments of the Cook Islands, Niue and Tokelau welcomed its application to people in their State or territory. 
sometimes makes laws that have important practical consequences for peoples or things in other parts of the Realm, although the statute concerned may not be part of their own law.

In "New Zealand" considered as part of the Realm, the Letters Patent and the office of GovernorGeneral provide the essential link between the powers and authorities vested in the Sovereign in right of New Zealand and their exercise by, or on the advice of New Zealand ministers. That aspect of the constitution is governed by the unwritten constitutional conventions, especially as they apply to the executive branch of government. Those aspects of the Letters Patent are more fully explained in chapter 7 of This Realm, and the operation of the constitutional conventions in This Realm chapter 9.

\section{The Self-governing State of the Cook Islands}

\section{The nature and effect of self-government}

The Cook Islands were brought within the boundaries of New Zealand in $1901 .{ }^{42}$ Letters Patent Constituting the Office of Governor or Governor-General of New Zealand made after that date have applied to the Cook Islands as part of "New Zealand". Even so, the Cook Islands were always separately administered. In 1946, the New Zealand government, while noting their legal status as part of New Zealand, recognised that, in reality, they were a "non-self-governing territory" for the purposes of the United Nations Charter.

The Charter provisions include the obligation to promote self-government. ${ }^{43}$ On 4 August 1965, the Cook Islands became a self-governing state in a relationship of free association with New Zealand. It did so under a Constitution drafted in consultation with the Cook Islands government, enacted by the New Zealand Parliament, ${ }^{44}$ and approved by a majority of the voters in the Cook Islands before its entry into force. ${ }^{45}$ From then on, the power to amend the Constitution has rested exclusively with the Parliament of the Cook Islands, acting in some cases with the approval of voters. That power has frequently been exercised. ${ }^{46}$

42 SR \& O (rev 1948), Vol XVI, 862. Order in Council 1901 No 531, 13 May 1901 - in force on 11 June 1901 by Proclamation in New Zealand Gazette 13 June 1901.

43 Charter of the United Nations, art 73.

44 For the Constitution as enacted, see the schedule to the Cook Islands Constitution Act 1964.

45 Cook Islands Constitution Act Commencement Order 1965.

46 The Constitution of the Cook Islands was officially reprinted as at 17 July 1997 with amendments incorporated in Rosemary Gordon and Tony Angelo Laws of the Cook Islands 1994-1997 (Crown in Right of the Cook Islands, 1997) vol 1 at 639. There have been seven amendments between then and 1 May 2019. See also the Constitution of the Cook Islands, available at Pacific Islands Legal Information Institute $<$ www.paclii.org $>$. 


\section{The Sovereign in the Cook Islands Constitution}

The head of state of the Cook Islands is Her Majesty the Queen in right of New Zealand. The Laws of New Zealand point out, however, that: ${ }^{47}$

[i]n that context, convention has supplemented or moved ahead of law so as to establish or confirm that, although the Queen in right of New Zealand is the symbol of the free association between the two countries, she is separately advised by her ministers in each country. [...] It must be understood ... that the reference to 'Her Majesty the Queen in right of New Zealand' does not reflect a notion that, as between New Zealand and the Cook Islands, the Crown is indivisible.

References to "the Queen in right of New Zealand" in the Cook Islands Constitution and other laws therefore have to be carefully considered in their context in order to determine their true effect.

Under the Constitution as enacted, a Council of State carried out a role analogous to that of a Governor-General in a Commonwealth realm. Its members were jointly the representative of Her Majesty the Queen in the Cook Islands. The presiding member, the "High Commissioner of the Cook Islands", was appointed by the Governor-General and was also the representative of the New Zealand government in the Cook Islands. Although the Cook Islands political leaders had favoured the High Commissioner's dual role, its problematic nature had been foreseen. ${ }^{48}$ The New Zealand government eventually left the office of High Commissioner vacant, and appointed its own "New Zealand Representative". In accordance with the Constitution, the functions of the High Commissioner as the presiding member of the Council of State were then carried out by the Chief Justice. ${ }^{49}$

In 1982, the Cook Islands Constitution was amended so as to replace the Council of State (and also the office of High Commissioner) with a "Queen's Representative". As the name implies, the Constitution provides that the Queen's Representative is the representative of the Sovereign in the Cook Islands, and is appointed by Her Majesty. Within the Cook Islands, the Queen's Representative is invested with the functions and powers formerly exercised by the Council of State.

Accordingly, the Queen's Representative has the range of functions and powers that are usual under the Westminster system. In words similar to those of the Letters Patent, the Queen's Representative is empowered to exercise the executive authority of the Cook Islands vested in the Queen in right of New Zealand, either directly or through subordinate officers. ${ }^{50}$ This authority includes the power to make treaties and exercise all the other attributes of a state at international law.

47 Laws of New Zealand The Self Governing State of the Cook Islands at [9]-[10].

48 The role of the High Commissioner mirrored the earlier role of the Governor, and later the Governor-General, as the representative in New Zealand of both the Sovereign and the United Kingdom government. By the time that arrangement ended in 1938, it had become increasingly problematic.

49 Constitution of the Cook Islands, art 7.

50 Article 12. 
Except as otherwise provided, the Queen's Representative must act on the advice of the Cabinet, the Prime Minister or other appropriate minister. Subject to the Constitution, the Cook Islands Parliament has a plenary and exclusive power to make laws for the Cook Islands. The Cook Islands therefore has the same constitutional attributes as a formally independent state. It has chosen, however, to remain in a relationship of free association with New Zealand.

\section{The appointment of the Queen's Representative in the Cook Islands}

(a) New constitutional conventions

The proposal that the Queen's Representative would be appointed by the Sovereign raised the question of how Her Majesty would be advised. Until then, there had been no reason to look beyond the recognised constitutional convention that the Prime Minister of New Zealand advises the Sovereign on matters relating to any part of the Realm of New Zealand. The Queen's household, however, was quick to recognise the implications of the Cook Islands Constitution. The New Zealand representative in the Cook Islands conveyed their view to the Cook Islands government in the following terms: ${ }^{51}$

It follows that as [there is] a sovereign Parliament with plenary powers and no legal fetters on the exercise of those powers the Cook Islands Government must be entitled to tender advice to the Queen on matters wholly within its competence without any substantive involvement on the part of New Zealand Ministers.

Building on that principle, the Premier (now the Prime Minister) of the Cook Islands and the Prime Minister of New Zealand were able to agree on a "six-point procedure" that would give the Sovereign the needed assurance that was in order for her to accept a recommendation made to her by the Prime Minister of the Cook Islands. ${ }^{52}$ The agreed statement contains a mix of principles and procedure. Subsequently, it was realised that the procedure had to accommodate the need to obtain the Sovereign's informal approval of a proposed appointment to the office of Queen's Representative before making a formal recommendation. So the "six steps" have become 12, or even more. There appears to be room for some simplification of the agreed process, as long as the following governing principles continue to be met.

51 Letter from the New Zealand Representative in the Cook Islands to the Attorney-General of the Cook Islands (28 October 1980), as cited in Letter from Hon Thomas Davis (Premier of the Cook Islands) to Rt Hon RD Muldoon (Prime Minister of New Zealand) CAB 3/1/6 (8 December 1980).

52 Letter from Rt Hon RD Muldoon (Prime Minister of New Zealand) to Hon Thomas Davis (Premier of the Cook Islands) (21 May 1981); and Letter from Hon Thomas Davis (Premier of the Cook Islands) to the Rt Hon RD Muldoon (Prime Minister of New Zealand) (10 June 1981). 
The first is set out clearly: ${ }^{53}$ Advice to Her Majesty on matters within the exclusive competence of the Cook Islands Government should be tendered by the Cook Islands Government.

That means that all communications to the Sovereign, both informal and formal, should be signed by the Prime Minister of the Cook Islands, and him or her alone. In general, this principle has been adhered to faithfully, although one or two inconsistent practices have crept in.

The second principle is implicit, but has not been articulated. It may be stated as follows. Because the Cook Islands remains part of the Realm of New Zealand, the Sovereign needs the assurance of her New Zealand Prime Minister that the matter on which she receives advice from the Prime Minister of the Cook Islands is indeed within the exclusive competence of the Cook Islands government. That is the rationale behind the agreement that the channel for informal or formal advice to the Sovereign from the Prime Minister of the Cook Islands is through the Queen's Representative in the Cook Islands to the Governor-General of New Zealand, ${ }^{54}$ and then from the Governor-General to the Sovereign's Private Secretary. Implicit in that arrangement is the fact that the Governor-General acts only on the advice of the Prime Minister of New Zealand.

In practice, the Prime Minister simply requests the Governor-General to forward to the Palace the expected letter or advice sheet signed by the Prime Minister of the Cook Islands. But what does that "advice" signify? Neither the New Zealand constitution nor that of the Cook Islands gives the Prime Minister of New Zealand any ministerial responsibility for the substance of the recommendation to the Sovereign. There are, however, some underlying implications going beyond the simple confirmation that the Prime Minister of the Cook Islands is indeed the exclusive adviser of the Sovereign on the matter in question.

Under the six-point procedure, the Prime Minister of the Cook Islands has agreed to: ... discuss informally the nature of such advice with the Prime Minister of New Zealand before the advice is tendered.

That discussion may legitimately go into the qualifications, experience and good character of the person proposed to be appointed, and even into the questions whether the appointment is likely to be generally acceptable in the Cook Islands and is consistent with the partnership between the Cook Islands and New Zealand. ${ }^{55}$ The subject matter lends itself to an oral briefing rather than a letter. The underlying objective is to avoid any possibility that the appointment could in any way cause

53 Exchange of Letters, above n 51 and 5252. See also Joint Centenary Declaration of the Principles of the Relationship between New Zealand and the Cook Islands, above n 36, cl 3(1).

54 In the case of a proposal to reappoint for a second term, the person already holding office as the Queen's Representative, the documents are sent to the Governor-General through the diplomatic channel, to avoid any appearance that the Queen's Representative is acting in a matter in which he or she has an interest.

55 Joint Centenary Declaration of the Principles of the Relationship between New Zealand and the Cook Islands, above n 36, cl 1 . 
embarrassment to the Sovereign. The two prime ministers can be seen as sharing the responsibility to uphold the royal dignity and integrity in all matters relating to the self-governing associated state.

Consistently with the principles just outlined, there may be room for some simplification, so far as is practicable, of the way in which the documentation is handled. The principles themselves reflect enduring values in the relationship between the Cook Islands and New Zealand. It is clear, however, that they do not affect the responsibility of the Cook Islands for the conduct of its own foreign affairs, and have no bearing on any aspect of its relationships with other members of the international community.

(b) The prerogative of honour

In This Realm we explained that a comprehensive New Zealand Royal Honours system has replaced the country's former participation in United Kingdom Royal Honours (formerly known as the "Imperial" honours system), under which honours are awarded on the formal advice of the United Kingdom Prime Minister. ${ }^{56}$ The government of the Cook Islands was invited to participate in the New Zealand scheme, but wishes to develop a Royal Honours system of its own. Meanwhile, it continues to participate in the United Kingdom Royal Honours system in the following way.

Recommendations by the Prime Minister of the Cook Islands are sent to the palace for informal, and later formal, approval with an accompanying request from the Prime Minister of New Zealand. The process takes account of the fact that the Prime Minister of the United Kingdom makes the formal recommendations to the Sovereign. Awards are announced by publication in a Cook Islands supplement to the London Gazette, as well as in Rarotonga. Other matters involving the exercise of the prerogative of honour, such as recommendations by the Prime Minister of the Cook Islands that the Sovereign approve a new flag, seal or other emblem, are dealt with in accordance with the principles that underlie the appointment of the Queen's Representative, as already described.

\section{The external affairs and defence of the Cook Islands}

(a) A transitional provision

As has been seen, the Governor-General of New Zealand has no role under the Cook Islands Constitution itself. But, in enacting the Cook Islands Constitution, the New Zealand Parliament preserved the executive authority vested in the Governor-General as advised by New Zealand ministers in respect of both the external affairs and the defence of the Cook Islands. ${ }^{57}$ The provision to that effect was seen as safeguarding what, at the time, was expected to remain an ongoing New

56 This Realm, above n 2, at 83.

57 Cook Islands Constitution Act 1964, s 5. Under the Constitution of the Cook Islands, an amendment to that Act in the law of the Cook Islands is treated as a constitutional amendment requiring, among other things, the support of two thirds of the eligible voters in a referendum: Constitution of the Cook Islands, art 41(2). 
Zealand responsibility, at least in the early years of self-government. Even so, the provision gave New Zealand no executive or legislative authority within the Cook Islands.

After self-government, the New Zealand government continued to act, for a period, in ways that bound the Cook Islands internationally, but it did so only with the agreement of the Cook Islands government. A provision preserving its power to do so remains part of the law of both New Zealand and the Cook Islands, but that provision did not detract from the plenary executive and legislative authority of the Cook Islands government and Parliament in the fields of external affairs and defence. Within a relatively short period, that government was recognised as itself exercising the responsibility for the external affairs of the Cook Islands.

It is safe to say that the government of the Cook Islands would now ask the New Zealand government to make an international commitment extending to the Cook Islands only in exceptional circumstances, and then only if the Cook Islands were for some reason unable to take the necessary action themselves. Taken alone, therefore, the residual executive responsibilities of the New Zealand government cannot be seen as good reason for extending the Letters Patent Constituting the Office of Governor-General to the Cook Islands as part of their law.

As we have shown, however, there were other reasons for taking that step. The Cook Islands remains part of what is a single realm. The Sovereign's prerogative constituent power is still part of the law of the Cook Islands, so far as its exercise is consistent with the Constitution. The allegiance to the Sovereign in right of New Zealand of the peoples of all parts of the Realm provides a basis for their shared New Zealand citizenship.

For those broad reasons, and with the prior approval of the government of the Cook Islands, ${ }^{58}$ the Sovereign declared in the Letters Patent Constituting the Office of Governor-General that the instrument is part of the law of the Cook Islands. ${ }^{59}$ In the associated state itself, the office of GovernorGeneral can be seen as reflecting the shared Sovereign and the common citizenship guaranteed by the Constitution. In recognition of the significance of the office, the Governor-General, when formally visiting the self-governing state, is accorded equal precedence with the Queen's Representative in the Cook Islands.

\section{The Self-governing State of Niue}

\section{Carving out its own path}

To the indignation of its people who had sought annexation by Britain, the island of Niue, along with their distant neighbours, the Cook Islands, was brought within the boundaries of New Zealand on 13 May 1901. From the beginning, the New Zealand government treated Niue as if it were part of

58 Letters Patent, above n 1, seventh recital.

59 Clause 19 
the Cook Islands in reality, as well as in law. It did, however, appoint a Resident Commissioner in Niue, as well as in the Cook Islands, and kept its revenue distinct.

Otherwise, it was generally assumed that what was good for the Cook Islands would also be good for Niue. On that basis, but without then making any separate inquiry, the New Zealand authorities sought to apply to Niue the steps towards self-government progressively being introduced in the Cook Islands. By 1963, however, the Niue Island Assembly, which was by then an elected body, made it clear that the people of Niue wished to follow their own path to self-government, if that was indeed their goal, and to travel that path at their own pace.

\section{The making and entry into force of the Niue Constitution}

We cannot here trace the steps that were taken both to give the people of Niue some experience of how a self-governing Niue might function in practice, and, at the same time assure them of New Zealand's continuing economic and administrative support. Like that of the Cook Islands, the Constitution of Niue gives that country the autonomy of an independent state. Even so, the free association between each of the self-governing states and New Zealand is a flexible relationship that can meet the sometimes different needs of each.

As in the Cook Islands, the New Zealand authorities had taken it for granted that a self-governing Niue would have a constitution on the New Zealand model. By the end of the 1960s, its people had acquired some practical experience of the workings of the Westminster system. In making a constitution for self-government, however, it was necessary to adapt the standard model so as to suit a country with a small and dwindling population, and limited human and financial resources.

The Constitution of Nauru 1968, which had by then become independent, was a helpful source of ideas. But, as a United Nations trust territory that had not been brought within the sovereignty of the Crown, Nauru had become independent as a republic. Niueans, however, are proud of their allegiance to the Sovereign. During World War I, a substantial number enlisted in the New Zealand forces. When Alison Quentin-Baxter visited Niue in 1970, an elderly veteran told her proudly, "I went to France to fight for the King". It was always clear that a constitution for self-government would need to recognise the Sovereign's role.

In 1974 the New Zealand Parliament enacted the Niue Constitution Act 1974. It is part of the law of New Zealand, as well as of Niue. There, both the Act and the scheduled Constitution have the force of supreme law. After being approved by a majority of voters in a referendum in Niue, ${ }^{60}$ the Act and the Constitution entered into force on 19 October $1974 .^{61}$

60 Alison Quentin-Baxter "Making Constitutions, from the Perspective of a Constitutional Adviser" (2002) 33 VUWLR 661.

61 Niue Constitution Act Commencement Order 1974. 


\section{The Sovereign and the Governor-General in the Niue Constitution}

It is implicit in the Constitution that Her Majesty in right of New Zealand is the head of state of Niue. That, however, was left unstated, as it then was in New Zealand itself. The Constitution begins with the following statement: "The executive authority of Niue is vested in Her Majesty the Queen in right of New Zealand, ...". It then continues: "... and the Governor-General of New Zealand is accordingly the representative of Her Majesty the Queen in relation to Niue".

It was seen as impracticable to provide for the Queen to be separately represented in Niue. In such a small community, that would have been out of proportion, as well as a drain on Niue's human and financial resources.

Perhaps because it seldom has practical consequences, the New Zealand advisers of the GovernorGeneral have been slow to realise that, in representing the Sovereign in relation to Niue, the GovernorGeneral must leave aside his or her role in respect of New Zealand or any other part of the Realm, and speak and act as Niue's person. In that capacity, the Governor-General is advised solely by his or her ministers in the self-governing state of Niue. Parliament's edict makes that clear: "Niue shall be selfgoverning". ${ }^{62}$ That provision of the Niue Constitution Act 1974, which is part of the law of New Zealand as well as that of Niue, makes it clear that the Letters Patent are subject to the Niue Constitution and the other laws of that part of the Realm.

Because the Governor-General, although the representative of the Sovereign, is not resident in Niue, the Constitution gives the Governor-General only one express function, and that function is capable of being exercised at a distance. It is the power to appoint and remove from office the Chief Justice and the other judges of Niue's High Court and Court of Appeal. In appointing those judges, the Governor-General acts on the advice of the Niue Cabinet, tendered by the Premier. In the case of a removal from office, the advice must be given in accordance with a recommendation contained in a resolution of the Niue Assembly, and then only on the ground of inability to discharge the functions of the office or misbehaviour.

As will be explained, the Constitution of Niue expressly or impliedly vests in another organ of the Niue government most of the other functions that, in New Zealand, are performed by the GovernorGeneral. But, if a need should arise for the Governor-General as the representative of the Sovereign in respect of Niue to exercise any function not so vested, then the Governor-General must exercise it on the advice of the Niue Cabinet tendered by the Premier. That is the proper course if, for example, the Governor-General receives a petition about something in Niue. Similarly, any statement by the Governor-General in or in respect of Niue should first be cleared with the Premier.

On such a matter, it is appropriate for the Governor-General or the Official Secretary to communicate directly with the Niue government and to act in accordance with the advice received.

62 Niue Constitution Act 1974, s 3. 
Like the Sovereign, however, the Governor-General may wish to have the confirmation of the Ministry of Foreign Affairs and Trade, or even of the Prime Minister, that the matter is indeed one in respect of which he or she must act on the advice of Niue ministers. There is, however, no reason to involve New Zealand ministers in the substance, and appropriate confidentiality should be maintained. If, however, the Premier of Niue were wishing to communicate with the Sovereign, the principles governing the appointment of the Queen's Representative in the Cook Islands should be regarded as a guide.

\section{A Westminster constitution without the Sovereign's representative}

The fact that the Governor-General represents the Sovereign in respect of Niue made it necessary for the executive and legislative branches of government to carry out their functions without any need for the Governor-General's personal involvement. There was also a strong desire to avoid the problems that had occurred elsewhere when doubts had arisen about the scope of a Governor-General's personal discretions. The solution to both problems was seen as being straightforward. The legislative and executive functions and powers should be exercised by those who had the political responsibility for their exercise.

Accordingly, the Cabinet of ministers of Niue is authorised to exercise the executive authority of Niue. The authority thus conferred on the Cabinet must be seen as including the exercise of the prerogative of mercy. Although that prerogative is expressly delegated to the Governor-General by the Letters Patent, that delegation does not restrict the scope of the executive authority of the various parts of the Realm, and does not extend to any part of the Realm where any other person or persons are authorised to exercise the prerogative of mercy. It is implicit, however, that the Cabinet ought to exercise that prerogative with the benefit of independent advice and without regard to political considerations. That convention is recognised in all the Sovereign's realms.

The Constitution of Niue also charges the Cabinet with the general direction and control of the executive government. The Cabinet may exercise such other functions and powers as are conferred on it by law. The Constitution itself codifies the constitutional conventions that, in the Westminster system, require the Premier and the other members of the Cabinet to maintain the confidence of a majority in the Niue Assembly, the legislative body.

The Premier is elected by the Assembly, which comprises the elected members of that body and the Speaker. That is a departure from the usual practice of making the Sovereign or her representative part of the legislature and conferring on them what are, on their face if not in reality, discretionary powers. The Speaker is elected by the Assembly but remains independent, without the competing responsibility of representing the electors of a village constituency or the island as a whole. Those functions were seen as incompatible, not only with the Speaker's function of presiding over meetings of the Assembly, but more especially with the other functions conferred on the Speaker in a country where the Sovereign has no resident representative. 
Under the Constitution, the Speaker has many of the functions that, in other circumstances, would be exercised by the Sovereign's representative. So, for example, the Speaker formally appoints the Premier and the other ministers, and also fixes the dates for doing certain important things, such as summoning a meeting of the Assembly, dissolving the Assembly and holding a general election. The relevant provisions may give the Speaker an element of discretion within the limits prescribed, or require prior consultation with the Premier, but the power itself is vested in the Speaker.

A Bill becomes law when the Speaker certifies that it has been duly passed by the Assembly. In the case of Bills amending the Constitution, the Speaker must certify that the applicable requirements have been met, including the necessary majority in a referendum of voters if that is required in the particular case.

In general, the allocation of functions under the Niue Constitution reflects the reallocation of the powers and authorities of the Governor-General achieved in more orthodox Commonwealth monarchies by the operation of the constitutional conventions. The Niue Constitution has the advantage of making it clear where the real responsibilities lie, while also providing for the exercise of formal powers. Outside the Assembly, the Speaker shares with the Premier the responsibility of ensuring that what ought to be done under the Constitution is in fact done. For the more than 40 years that the Constitution has been in force, that aspect of it has worked smoothly.

The Constitution of Niue is not a republican constitution. Because, however, it vests powers in the Governor-General as the Queen's representative in respect of Niue only for the purpose of making appointments to the High Court, and then sets out the conditions for their exercise, ${ }^{63}$ the structure of the Constitution as a whole can be seen as a model for a republican constitution, while still being cast in the Westminster mould.

\section{The significance of the Governor-General's role in relation to Niue}

The Governor-General's role in relation to Niue recognises that Her Majesty the Queen in right of New Zealand is the head of state of Niue. As well as providing for the appointment, on the advice of Niue ministers, of the judges of the superior courts, the role symbolises the people's loyalty to their Sovereign and their free association with New Zealand. It should therefore be seen as significant, not only within the self-governing State of Niue, but also as an element of the "enduring, unique and special partnership established under the Niue Constitution" between New Zealand and Niue.

The partnership with New Zealand is Niue's lifeline. In the run-up to self-government, the constitutional adviser to the Niue Island Assembly recorded his sombre conclusion: ${ }^{64}$

63 As already mentioned, the Governor-General makes the formal appointments of the judges of the superior courts.

64 RQ Quentin-Baxter "Second Report to the Niue Island Assembly on the Constitutional Development of Niue" (1999) 30 VUWLR 577 (which reproduces a message to the Leader of Government dated 4 March 1974). 
It is an irreversible consequence of Niue's association with New Zealand that every Niuean is influenced by New Zealand values, and is accustomed to living standards that the resources of the island cannot sustain. ... [T] he tranquil surface of Niuean life conceals a crisis more urgent and relentless than any hurricane. In ever increasing numbers, the people of Niue are leaving their island, and few of them return.

The constitutional adviser therefore recommended that the Niue Constitution Act to be enacted by the New Zealand Parliament should contain a guarantee that the government of New Zealand, acting in consultation with the government of Niue, would continue to provide economic and administrative assistance to Niue. Equity required that ongoing assurance: ${ }^{65}$

The free movement of men and women from Niue to New Zealand cities has strengthened the New Zealand labour force and has weakened the island community. It is therefore equitable that New Zealand's aid to Niue should be on a substantial scale; but, if this aid is to achieve the desired result, it must be planned and administered in a genuine partnership between the Governments of the two countries.

By 1974, when Niue became self-governing, its destiny was already bound up with its relationship with New Zealand. If the day were to come when the partners no longer owe allegiance to a common sovereign, some would regret the abandonment of cultural values rooted in the history of both. But those regrets would not halt or slow the speed of what has become an irreversible process. In every generation the partner countries become more closely linked by the common culture developing so vigorously in the soil of each. No assumptions should be made about the form their association may eventually take, although self-government in free association is capable of accommodating a greater range of possibilities than many people suppose.

\section{E Tokelau}

\section{The general approach}

I have shown already that, although, constitutionally, Tokelau forms part of New Zealand, in international law it is a New Zealand non-self-governing territory for the purposes of chapter XI of the United Nations Charter. It is also a territory for whose international relations the government of New Zealand is responsible. In practice, however, Tokelau enjoys a considerable measure of selfgovernment. In recent years, a major effort has been made to structure its own institutions of government in ways that reflect the traditional practices of its people, while including the necessary innovations to meet modern needs. This approach, sometimes described as "building the modern house of Tokelau", has deliberately moved away from any reproduction of a Westminster constitution. It is, however, a work in progress. For the time being, the New Zealand government retains its controlling mechanisms, even if they are seldom used. 


\section{Legislative powers and executive authority}

The New Zealand Parliament, the Governor-General acting with the advice and consent of the Executive Council (the Governor-General in Council) and the General Fono of Tokelau each have a plenary power to make laws for Tokelau. ${ }^{66}$ The three bodies constitute a hierarchy. The laws made by those lower in the hierarchy are of no effect if inconsistent with those made by a higher-ranking body. ${ }^{67}$ The extent of the legislative power conferred on the Governor-General in Council in respect of Tokelau is as wide as that of Parliament itself. The statutory conferment on the Governor-General in Council of a power to make subordinate legislation is, in itself, a commonplace. So also is the enactment of such a wide power in respect of a non-self-governing territory, although contrary to constitutional principle in respect of New Zealand itself.

Turning now to the exercise of executive powers, Tokelau was annexed as part of the Sovereign's dominions, and is now part of New Zealand. The executive authority of New Zealand vested in the Sovereign therefore extends to Tokelau. Under the Letters Patent, that authority may be exercised by the Governor-General, directly, or through subordinate officers, but that general provision has been superseded by a more specific arrangement. In the exercise of the legislative power conferred by Parliament, the Governor-General in Council authorised the Minister of Foreign Affairs and Trade to appoint an Administrator of Tokelau. The Administrator is charged with the administration of Tokelau's executive government, subject, however, to the Minister's control. ${ }^{68}$

Because Tokelau is still a non-self-governing territory, New Zealand remains the administering authority. The Governor-General has no separate role as an organ of the government of Tokelau, and the Sovereign is not separately represented in respect of that territory. If the Governor-General were to visit Tokelau, he or she would do so as the Sovereign's representative in New Zealand.

Yet, as we have shown, Tokelau is not, for all purposes simply "part of New Zealand", like the outlying islands. It has a separate legal system and its own governmental arrangements, although each is overlapped by those of New Zealand. The General Fono, a meeting of elected and ex officio representatives of the three atolls is seen as exercising both legislative and executive powers. It, or if it is not in session, the Council for the Ongoing Government of Tokelau, constitute the government of Tokelau, and interact with the New Zealand government. That government, however, also interacts directly with the village councils known as the taupulega. Tokelau is therefore regarded as a distinct part of the Realm of New Zealand. As its own institutions of government develop, its separate status

66 As to the full power of Parliament to make laws, see generally This Realm, above n 2; as to the power of the Governor-General in Council to make regulations for the peace, order and good government of Tokelau, see the Tokelau Act 1948, s 4; and as to the power of the General Fono to make rules for the peace, order and good government of Tokelau, see Tokelau Act 1948, s 3A.

67 Tokelau Act 1948, ss 3B and 4.

68 Tokelau Administration Regulations 1993, reg 4(2). 
is likely to be reflected in changes to the powers in respect of Tokelau of both Parliament and the Governor-General in Council. That said, the people of Tokelau have twice declined to approve in a referendum a proposal that Tokelau should become self-governing. Its future path is therefore unclear.

It should not be assumed, however, that (leaving aside independence) the only acceptable alternative to self-government is for Tokelau to become ever more closely integrated with New Zealand. This is not the place in which to explore the concepts of self-government or of integration with an independent state as United Nations approved outcomes of an exercise of the right of selfdetermination. Each concept, but especially self-government, embraces a wide range of possibilities. Their further investigation, however, should be put to one side until the people of Tokelau have had more experience in making their own institutions of government work well. Already, a great deal has been achieved. One step in particular has altered the working relationship with New Zealand, and also the division of authority within Tokelau itself.

\section{Steps towards self-government}

The Tokelau Administration Regulations 1993 authorise the Administrator to delegate to the General Fono or to other persons in Tokelau all or any of the Administrator's powers, subject, however, to certain conditions. Within the limits of the delegation, the authority so delegated is as full as if conferred directly, but the delegation is revocable at will, and does not prevent the exercise of a power by the Administrator in person. If the General Fono is not in session, a power delegated to it may be exercised by the Council for the Ongoing Government of Tokelau, a body established by Tokelau law.

Initially, the Administrator delegated the powers of that office to the General Fono. But, in the customary law of each of the three Tokelau villages, all governmental power is vested in the village councils - the taupulega. In accordance with the policy of developing within Tokelau a system of government that reflects traditional values, governmental powers are, so far as possible, vested in the taupulega. It was therefore thought appropriate to repeal the earlier delegation of the Administrator's powers to the General Fono. Instead, the Administrator delegated those powers to each of the three taupulega, to be exercised by it jointly and cooperatively with the other villages of Tokelau. Each taupulega is expressly authorised to further delegate its powers, jointly with the other villages, to the General Fono. Accordingly, the three taupulega jointly delegated their authority to the General Fono, now seen as having the responsibility of managing the matters listed in the instrument of delegation in the interests of the nation. Those matters are regarded as outside the areas that can properly be undertaken by any of the villages, acting alone.

The recognition that the General Fono and the Council for the Ongoing Government of Tokelau derive their executive powers by delegation from the taupulega was intended to promote public support for a system of central government. The powers themselves, however, are still those of the Administrator. Some of them are statutory, conferred on the Administrator by or under the authority 
of an Act of the New Zealand Parliament. In addition, however, the delegation extends to the prerogative powers that are vested in the Sovereign by the common law.

Under the Tokelau Act 1948, the common law is part of the law of Tokelau, to the extent there provided. As in other common law countries, the law in question must be applicable to Tokelau's circumstances and consistent with its statute law. Naturally, there is a tendency to suppose that the people of Tokelau have little or no practical need to concern themselves with the mysteries of the common law, but that may not always be the case. As well as recognising the prerogative powers of the Crown, the common law is a residual source of law, not only where there is no relevant statutory or customary law, but also as an aid to the administration of the codified law, whatever its original source.

It is of interest that few, if any, of the countries that received the common law of England as part of their law have subsequently excluded its application. For the most part, the common law may sit almost unnoticed alongside the statute law and a written constitution as well as the customary law, but it can still be drawn upon if the need should arise. Then it is often a source of illuminating principle, especially in interpreting and applying the constitution, even if the constitution itself draws its inspiration from its people's Indigenous roots. ${ }^{69}$

69 Constitution of the Independent State of Papua New Guinea, preamble. 
(2021) 52 VUWLR 